\title{
New perspectives on China's foreign and trade policy
}

Sendil Murugesan(10)

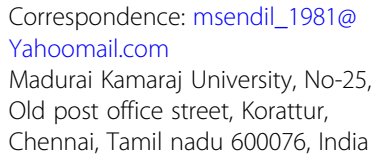

Correspondence: msendil_1981@ Yahoomail.com

Madurai Kamaraj University, No-25, Old post office street, Korattur, Chennai, Tamil nadu 600076, India

\begin{abstract}
The rise of the Asian giants has shifted the economic focus away from Europe. Superficially there seems to be a developing cooperation between them leading to increased globalization. China's ability to exercise power by economic means is now visible to all. Huge infrastructure projects, funded by soft loans is a characteristic feature of Chinese diplomacy. The consolidation of strength in the South China Sea is seen by its neighbours as evidence of China's aggressive territorial ambitions. The Trump Administration's plan to play safe with China by avoiding ratcheting up tensions will cede great freedom to the latter in its pursuit of its goals. The US has shown little interest in prolonging the Asia strategy formulated by Barrack Obama. It remains to be seen how well China can perform the balancing act: maintaining cordial relations with both Europe and the US.
\end{abstract}

Keywords: 1962 war, U.S, Triagonal relationship, ASEAN, South China Sea dispute, OBOR

\section{Introduction}

The rise of the two Asian giants China and India has altered the geopolitical equations considerably. Concerted action between India and China will help to stabilise and steer the world from potential conflicts. A major shift from Deng Xiaoping's policy of lying low occurred as Jiang Zemin started to enter the international community in the mid 1990s (Xuanli Liao 2006). Jiang Zemin's 1996 visit to India was an major breakthrough in bilateral relations between the two nations. China will exert its strength in a phased manner, beginning with the careful cultivation of allies followed by the gradual edging out of its competitors. China is not ready to directly confront America, nor it is willing to sacrifice its trading interests. A fine balance must be sought between the two options via a form of realpolitik. Political analysts are of the opinion that China's intentions are to test America's patience by enticing their allies to shift positions. The strategy of isolating of each other's allies is apparent in China's moves to lure Eastern European allies and America's renewed focus on the Pacific theatre.

Both nations will attempt to out-manoeuvre the other in an intricate game of commerce and diplomacy.

The Trump administration has upped the ante by selling F-16 fighter jets to Taiwan. China strongly opposes any act which it perceives to be interference in its internal affairs by foreign countries. Peaceful transition to democracy should be a higher priority for China than confronting America. America siding with the Russians against China is considerably

(c) The Author(s). 2018 Open Access This article is distributed under the terms of the Creative Commons Attribution 4.0 International License (http://creativecommons.org/licenses/by/4.0/), which permits unrestricted use, distribution, and reproduction in any medium, provided you give appropriate credit to the original author(s) and the source, provide a link to the Creative Commons license, and indicate if changes were made. 
less likely owing to domestic opposition. This is similar to the détente of the 70s or the triangular diplomacy promulgated by Henry Kissinger (Henry Kissinger 2011). China is well aware of the pitfalls associated with Thucydides trap and would prefer to steer away from confrontation (Allison 2017:pp.150-152). The international community needs to recognise China's legitimate claims and share responsibility for maintaining global security. Conflict clearly would derail its long-term growth. China continuing to postpone a forceful settlement over Taiwan is a testimony to the fact that it is charting a peaceful rise.

The expelling of China from the RIMPAC exercise and the sailing of American warships close to the Paracel islands demonstrates America's resolve to defend its interests in the Indo-Pacific region.

Freedom of navigation operation in South China Sea should be supported by bilateral discussions towards securing maritime rights, a far better approach would be to raise the security issues in multilateral forums. China has not been as anxious about acquiring the great power identity as has been projected, as it's huge geographical size and population naturally bestows upon it the status of regional power. China is willing to bide time at the top as America's power wanes. This approach is evident in China's increasing engagement with India, despite the latter strongly allying with the U. S and agreeing with France on cooperation in the Indian Ocean region. America has been ceding influence to China owing to geopolitical and economic issues; this might seal the fate of the liberal world order if left unchecked. The absence of a hotline between the two nations is making things more complicated.

\section{Trans continental ambitions}

China is filling the void created by the declining influence of America in conflict hit regions. Iraq and Syria have become more inclined towards china because of western military intervention in their respective countries. Beijing wields considerable influence over Syria by virtue of being the leading arms supplier to the Middle Eastern country. ${ }^{1}$ The predominance of China in Syrian affairs is evident by the fact that it had used veto power four times against UN Security Council resolutions on Syria. The high profile visit of Guan Youfei, head of the office of military cooperation to Syria reflects the level of importance attached by China to speedy resolution of the conflict. In his address to the 18th Shanghai Cooperation Organization, Xi Jinping expressed his interest in promoting the international order to prevent and resolve conflicts.

"While hegemony and power politics still persist in this world, the growing call for a more just and equitable international order must be heeded. Democracy in international relations has become an unstoppable trend of the times" (Xinhuanet 2018).

China enjoys strong cooperative relations with Iraq and has now become the largest investor in the latter's oil sector. In fact, more than half of the oil produced in Iraq is exported to China. There has been a steady increase in the number of Chinese workers being employed abroad, and this has contributed to redistribution of labour and improved productivity.

China had made large scale investments in Libya and Syria before the outbreak of hostilities. The crisis situation in Libya forced the evacuation of 38,000 Chinese nationals working there. CPEC would meet a similar fate if hostilities breaks out 
between India and Pakistan. According to the recent estimates, around 8000 Chinese are currently working in the cpec project. The questions remain over safety of China's external investments, and it needs to devise mechanisms to safeguard them. China needs to play game changing roles in Syria, Afghanistan rather than limiting itself to facilitating talks between the government and rebel factions. The setbacks suffered in Libya, Crimea will only be temporary losses for China and it will regain it's influence, as it has happened in Iraq.

In the aftermath of the western sanctions, Russia has intensified its cooperation with China starting with a deal for the purchase of $\mathrm{Su}-35$ fighter planes and S-400 missile system. A long term perspective on China is necessary for Russia, to act accordingly, irrespective of the fluctuations in global trends. The development of Russia as a manufacturing base will help China to reduce transportation costs incurred on exporting to Europe. Chinese haven't invested in the Russian manufacturing sector in a big way. This is probably because of their reluctance to share their expertise in low cost manufacturing. Similarly, China's investment in India for the last 17 years stands at a paltry level of $\$ 1.67$ billion.

Increasing copyright infringements are a major cause of concern for business firms operating in China. There are apprehensions among Russians over China copying the designs of SU-35 fighter jet's engine AL-117 s.Special attention has been paid to the Russia's far east region. So far, many state owned Chinese firms like Great wall motors, Sanxia general company have invested there. Russia has expressed interest in the joint development of long range airliners with China after India responded slowly to the same offer. The Russian oil firm Rosneft has acquired the Indian petrochemical refinery Essar for \$13 billion and the strong bilateral relationship between the two countries helped in closing the deal.

The Chinese bid for German chip manufacturer Aixtron failed to succeed due to objections from the U. S at the highest levels. This incident highlights the trust deficit which exists between China and western nations. ${ }^{2}$ Germany and India are both similar in having strong economic and moderate political ties with China. China has strengthened cooperation with Israel by offering them the status of a junior partner. Israeli Prime Minister Netanyahu recently said that his country's technology could significantly quicken the progress of the two Asian powers. The investments from Chinese entrepreneurs are boosting the Israel economy in a big way, particularly in the field of infrastructure. Israel and Germany remain potential sources of sophisticated technology for China. Although Indo Israeli defence cooperation started earlier in the 1960's, China was the first to procure the sophisticated harpy drone from Israel back in the early 1990s.Israelis have held discussions with China on the recent developments in Iran's nuclear program.

The Made in China 2025 initiative promoted by their government, aims to make their nation a global leader in the fields of Semiconductor technology, Artificial Intelligence. Local Entrepreneurs are offered tax based incentives to encourage them to develop expertise in the field of cutting edge technologies. IBM and Apple have opened data centres in China, in order to comply with the new regulation for technology firms to operate there. The policies like made in China, India serve to promote indigenization of foreign firms in their respective countries. Chinese firms are trying to acquire western technology by investing in European start ups (Shambaugh 2011:pp. 200-204). Western countries regard India as a trustworthy partner, and are therefore, willing to provide high level technology to India. It will only be a matter of time before Chinese companies start competing with western technology firms on equal terms. 


\section{Iran as the central point of coordination}

China supports Iran as a strategic partner to strengthen its position in Eurasia (Harold and Nader 2012:pp.14-16). Since the late 90s, as a member of the EU + 3, China played a major role in the securing the agreement on joint comprehensive plan of action on Iran's nuclear agreement. Throughout the last two decades, America has consistently applied pressure on China to end it's collaboration with Iran on nuclear technology. But such measures are no longer effective against a resurgent Beijing. China is cautious to avoid antagonizing U. S and Riyadh while supporting Iran.

Russia has held back the supply of s-300 missiles to Iran owing to western pressure, and such attitude might force Iran to examine ways on reducing its dependance on the former for military hardware. Thus, cooperation with the China is not only commercially important for Iran, but also crucial for it's security. ${ }^{3}$ Chinese company ZTE has agreed to pay a fine of $\$ 1$ billion for illegal export of goods containing American components to Iran. The trade turnover between Russia and Iran stands at a paltry $\$ 2$ billion whereas China Iran trade is worth $\$ 22$ billion. Iran will function as a transit hub in the obor project by connecting to the Caucasus and Middle East. In this way, Teheran will promote China's trade interests in Eurasia. The Chabahar port in Iran provides an alternative to bypass the Pakistan land route to Afghanistan.

\section{OBOR-building blocks of socialism}

Pakistan continues to remain as China's all weather friend (Vandewalle 2015). Defence cooperation between the two sides are at an all time high with the joint production of fighter aircrafts JF-17 and FC-Xiaoning in Pakistan. Pakistan has slowly drifted away from the American camp and has placed itself on the Chinese side. The China-Pakistan economic corridor is developed as a part of the obor project. The cpec route passing through the disputed region of Kashmir remains a matter of serious concern to the Indian establishment. Expecting India's participation in the cpec is more of wishful thinking than solid logic. Upon lack of transparency in information sharing about the cpec, doubts have started to arise in the minds of ordinary Pakistanis on whether the cpec is imposed on them. The supply of M-11 missiles by China to Pakistan in 1993 was a disappointment for those hoping for a revival of Indo-China ties.

Pakistan's Prime Minister Nawaz Sharif inaugurated the power production from 340 MW Chashma 3 nuclear power plant on December 29, 2016.The Chashma 3 plant has been built with technical, financial assistance from China atomic energy authority and export -import bank of China. The ongoing construction of Karachi-2,3 nuclear plants is a joint collaboration between the Pakistan atomic energy commission and China national nuclear corporation. The China Pakistan economic corridor proceeds through the Karakoram highway in Pakistan before finally reaching the Chinese province of Xinjiang. CPEC offers a good opportunity to wean away the Uighyurs in Xinjiang and tribal militia in northern Pakistan from the influence of terrorism. This trade initiative will help Xinjiang to grow in the same manner as Shenyang province has done in this decade. Security restrictions in Xinjiang province are posing difficulties for the visiting Pakistani business men. One of the major drawbacks of cpec is the lack of rail connectivity, and the intended solution of constructing the Khunjerab rail line 
between Havelian and Kashgar will take about 5 years to be completed. There is always the possibility of a major terrorist attack bringing the whole process to a standstill.

\section{The road to debt trap}

Pakistan's manufacturing sector has received less investment from China owing to reasons like uncertain political climate, adverse security situation. The prospect of economic collaboration with China carries risk of being dumped with cheap imports (Ramay 2016). The large scale flooding of Chinese goods could adversely impact the Pakistan's fragile economy. Such fears aren't totally unfounded as Pakistan's trade imbalance has increased with imports from China rising by $29 \%$.Pakistan will have to spend around $\$ 5$ billion as debt repayment in 2022.Pakistan could end up being in a debt trap if the cpec fails due to financial or geopolitical reasons.

The general criticism that China's allies are being forced to spend on extravagant projects isn't completely untrue. Colombo port city project has incurred huge costs and the profits margins are low. It will be difficult for smaller economies like Srilanka to manage the risks associated with high costs projects. The problems surrounding the Hambontota port has been resolved to a certain extent after the Chinese firm Merchant Holdings signed a deal to buy $70 \%$ stake in the port for $\$ 1$ billion (Rutnam 2017). The obor project should be allowed to develop its own identity and steps should be taken to reduce spending. Srilanka has an outstanding debt of 8 billion dollars to be repaid to China. Nations participating in the Belt Road Initiative could end up in a similar state unless the debt issue is addressed (Vince F. Nonato 2017). Obor will prove to be a litmus test for Chinese ambitions. India boycotted the inaugural ceremony of the obor and has warned the participating nations of an unsustainable debt trap.

The overseas investments made by China are mostly in the field of infrastructure and comparatively less in the industrial sector. Given its vast accumulation of American treasury notes, spending on infrastructure projects is a convenient way for china to convert them into assets. After gaining a foothold in the BRICS countries, it would seek to develop other infrastructure projects available there. There has been a gradual increase in the number of Chinese workers being employed in infrastructure projects abroad. This new policy would help to redistribute labour and improve employee productivity. India had received strong financial and technological support from Soviet Union during it's formative years, a similar kind of approach by China will be helpful for poorer countries. The Mysitone dam project in Myanmar, Hambanota project in Lanka have run into environmental road blocks. Poor working conditions, lack of environmental safety plague the industrial sector in China, thereby giving room to suspicion that similar conditions might prevail in their collaborative ventures. ${ }^{4}$

\section{Uneasy neighbours: China and Japan}

Japan has been in the forefront in building a coalition to deter unilateral Chinese actions and conducted it's first ever joint patrol with the U. S in the South China Sea. India will have an integral role to play in the Japan's Free and open Indo Pacific strategy and this should be seen in conjunction with the Quad plan of the U.S. India and Japan are jointly working towards the creation of an Asia-Africa Economic Corridor (AAGC).AAGC differs from OBOR in its vision for wholistic development of the African continent rather than driven by commercial interests. There is close 
cooperation between India and Japan to counter the growing influence of China in Asia. ${ }^{5}$ Japan has funded the expansion of the Mombasa port in Kenya and has expressed interest in developing the Iranian port of Chabahar. After implementing many high speed rail projects back home, China is beginning to implement them in other countries. Being the leader in high speed rail technology has helped japan to bag the Ahmedabad-Mumbai bullet train project in India.

Vietnam has recently signed agreements worth $\$ 8$ billion with America. India's strategic interests matches the official Vietnamese policy of three No's (Brewster 2012:pp. 95-98). The three no's policy stresses on avoiding military alliances and discourages pitting India against China. India has been at the forefront in helping developing nations and does so irrespective of monetary benefits. This generous attitude of India makes for a natural partnership with third world countries. The see -saw battle between China and Vietnam continued at the 2017 ASEAN summit on the latter' insistence on including the code of conduct for South China Sea in the final declaration. The Mekong rice delta in Vietnam faced a crisis situation, after China started construction of a dam on the Lancang River in the Yunnan province. Water scarcity and maritime security will be matters of equal importance for lower Mekong countries like Cambodia and Vietnam (Li and Kwa 2011: p.105-108).

India had to face a similar situation when China commenced work on dam across the Brahmaputra River. Bangladesh and Burma joined India in protesting against the construction of dam, thereby forcing the project to be temporarily halted. But China will retain this option for use during conflict like situations. The inner logic behind China indulging in provocative actions like trespassing of borders, hot pursuit of fishing vessels, is to send a warning signal to its neighbours. Nevertheless, to presume that China would restrict itself to the Asia region is unrealistic, since it has made no secret of it's eagerness to expand influence across the borders. America has been encouraging India to get more actively involved in the South China Sea affairs. The renaming of the Pacific command as Indo-Pacific command underlines the importance of India as a strategic ally, and entrusts it with the responsibility to safeguard the region. India and other Asian nations stand to gain from the tussle between China and America.

\section{Troubled waters}

The dispute over South China Sea arose after China commenced offshore rigging in the region during 2014.China has certain reservations regarding the ASEAN forum and prefers to resolve disputes bilaterally with the neighbouring countries (Hong 2015: pp. 170-175). The solution offered by China consists of formulating a legally non binding, code of conduct for dealing with the dispute. Beijing has rejected the Hague tribunal's ruling on the South China Sea and opposes third party mediation in matters of national interest. ${ }^{6}$ U.S Defence secretary James.N.Mattis blamed China for reneging on it's promise to avoid militarization of disputed islands during his speech at the Shangri-La dialogue, Singapore. On the contrary, China believes it has a legitimate claim to the islands and views the disputes as remnants of its Colonial past.

Asian nations are caught in a piquant situation on giving assurances over their allegiance to the U.S. led alliance. Fears of disruption to the trade worth $\$ 5$ billion in South China Sea, certainly makes ASEAN countries to rethink any move against China. China's clever maneuvers has disturbed the delicate relationship between America and 
ASEAN countries. ${ }^{7}$ Philippines, a long time ally of America has shifted its allegiance to China. In a similar move, Cambodia has cancelled annual joint military exercise with America. Indonesia has now renamed the South China Sea as North Natuna Sea. China and Nepal recently conducted their first ever military exercise named Sagarmatha friendship. Nepal has recently signed an agreement with the Chinese firm Gezhoubha Group Corporation to build a $1200 \mathrm{mw}$ hydroelectric project in Buddhi- Gandaki at a cost of 2.5 billion. The rebel faction in Myanmar receives strong backing from Beijing and this is a worrying factor for the ruling military junta.

\section{The North Korean conundrum}

The Kim Jong Un 's regime continues to indulge in sabre rattling despite intense pressure from the U.S. America is deploying the Thaad missile defence systems in South Korea to thwart any possible North Korean offensive. North Korea has become a bargaining chip for China to extract concessions from America (Freeman 2015). America had briefly relaxed it's stance on negotiations with north Korea, until the latter started a flurry of missile tests. Being aware of the Libyan model, North Korea is relying on security guarantee from China to proceed on denuclearization.

Eruption of smaller conflicts in South East Asia will always remain a possibility rather than a full scale war. ${ }^{8}$ America's anti access area denial capabilities are primarily directed towards the Chinese navy. The shortage in aircraft carriers makes the Chinese more vulnerable to economic blockade by sea. China is making efforts to reduce it's vulnerability on the naval front and this is demonstrated by the induction of DF-21 missile, which is specifically designed to target aircraft carriers (Rinehart 2016:pp. 20-21).

The total strength of People's liberation army has been reduced below one million for the first time, to focus more on the naval and missile areas. Chinese military programme relies more on ballistic strength to compensate for its weaknesses in other areas. Any judgement on China's missile strength shouldn't be based on comparison with America's arsenal. The major reason behind China adopting a no first policy of nuclear weapons, is to convince the world of its peaceful intentions. Prolonged military deployments in Iraq and Afghanistan has weakened America's ability to start new offensives. The gap in military strength between America and China has narrowed over the past decade.

\section{Building a stable partnership}

\section{Bridging the trust deficit in Indo-China ties}

Beijing's diplomatic relations with neighbouring countries are entangled in border disputes inherited from it's colonial past. The hardline faction of the Chinese Politburo favours the use of force to resolve conflicts like that of Taiwan. However, it would be illogical to fritter away the economic gains of the last decades by indulging in war-mongering. India desires to maintain a peaceful relationship with China, but remains firm on it's stand regarding Arunachal Pradesh province being an integral part of its territory (Lintner 2018; Saran 2017a, 2017b). The border dispute has reared its ugly head again as China has renamed 6 places of Arunachal Pradesh in Chinese language.

The issuing of stapled visas by china to Indian citizens belonging to the state of Arunachal Pradesh had stirred up a controversy in 2011.Indian prime minister Modi and Chinese president Xi Jinping met at the Chinese city of Wuhan for an informal summit on April 
27-28 2018, speaking at the summit, Xi Jinping calmed fears of an showdown with India by stating that border dispute was of a limited and temporary nature. The president further stated that

"As the two largest developing countries and emerging-market economies with a population level of more than one billion, China and India are the backbone of the world's multi-polarization and economic globalization," "A good China -India relationship is an important positive factor in maintaining world stability and is of great significance to the promotion of the development of all mankind," (PTI. 2018).

India's efforts at the U. N security council to designate Jaish-e-Mohammed leader Masood Azhar as a international terrorist were blocked by China. Such efforts to shield Pakistan based terrorist leaders show a lack sensitivity to India's concerns. Trade between IndoChina is on the rise, though the prospects of closer ties are still uncertain. ${ }^{9}$ Indian Prime Minister Narendra Modi's initiative on manufacturing is largely inspired by the Made in China 2025 policy, which is in turn influenced by Germany's 2.0 policy. India is trying to match China's progress in infrastructure with projects like the $1360 \mathrm{~km}$ highway with Myanmar, Thailand. There has been no major economic or industrial partnership between India and China in the past and the recent free trade agreement talks have also got stalled. Modi's administration has refused to sign the transpacific partnership deal and the free trade agreement with China (Schott et al. 2012:p. 52) A major economic treaty between the two nations will provide the impetus for a stronger relations. India will have a crucial role to play in determining the success of Beijing's dynamic moves in Asia.

\section{Sharing global responsibility for a multipolar world}

Any attempts to delay or deny a permanent seat for India in the United Nations Security Council would be contrary to China's ambitions to create a multipolar world. Deng Xiaoping's vision of an Asian century would remain unfulfilled without substantial contribution from India. By virtue of being the world's largest democracy, India has a natural right for permanent membership in global institutions. India has been admitted to the Shanghai cooperation organization as a full member which provides an opportunity to discuss with China on a wide range of issues. India will have to demonstrate higher levels of flexibility to accommodate Chinese interests.

The Malabar exercise involving the navies of U.S, India and Japan were held on July 102017 in Chennai. While the American naval command stressed on the inter operability factor as a crucial element in such exercises, their Japanese counterparts admitted gaining operational capability in the Indian Ocean region. The naval exercise was watched cautiously by China, as it is worried that a coalition of this magnitude might undermine its dominance. The general perception of India trusting the Western nations over China isn't untrue either.

\section{The string of pearls strategy}

China is focusing on developing port infrastructure abroad which can be used to dock it's naval ships. The examples for such ports are Djibouti, Hambontota in Srilanka. The Marine Corps to be deployed in Djibouti would range around 20,000 to 1,00,000 troops. In the recent years, China has been constructing ports in India's neighbourhood, which 
resembles like a string of pearls around India's neck. The docking of Chinese submarines in the Colombo port had recently created a furore in India. It may be noted that Colombo has made efforts to placate India by offering the Triconamalee port, but India has declined the offer. Indian naval personnel are being high trained by the American navy personnel to track Chinese submarines operating in the Indian Ocean. India has procured the maritime surveillance aircraft Poseidon to serve the same purpose.

\section{New horizons in Eurasia}

Chinese president, Xi Jinping has mooted the setting up of cross border economic cooperation zones in obor nations. The cross border economic zone in Khorgos, Mongolia, the first of its kind, has been developed in collaboration with the China. Mongolia has also been requested to consider setting up a free trade zone based on the Khorgos model. Serious differences have cropped up between the two sides after Dalai Lama's official visit to Mongolia, and China has reacted by imposing severe border restrictions. The foreign trips of Dalai Lama and the visits to the war shrine in Japan by the heads of states provoke China the most.

Kazakhistan and Krygistan receive strong support from china in the form of financial assistance. China has invested about $\$ 42$ billion in Kazakhistan. The power sector in Krygistan has received a boost with the construction of Bishkek thermal power station and Kazarman hydro power plant with financial support from China. The Regional Comprehensive Economic Partnership promoted by the ASEAN, has finally emerged from the shadows of Trans-Pacific Partnership. The cut on tariffs prescribed by the Regional Comprehensive Economic Partnership would hurt the interests of India and other countries like South Korea and Malaysia which enjoy a trade surplus with China. The prospect of joint ventures with local firms would help to allay fears of job loss for native workers.

China would gain from developing consensus among coalition partners than resorting to pressure tactics. Despite its strained relationship with Vietnam and Mongolia, China has invited both to participate in the obor project. China has allocated specific roles to allies to maximise cooperation. While Iran is being developed as a strategic partner, Pakistan remains a trusted defence partner. Ukraine and Russia are being tapped for their agricultural resources. Beijing has lacked a strong partner like Britain has supported America. The efforts to cultivate new friendship through financial assistance programs serves to boost its global image.

Poland and Serbia are the main partners for China in central Europe. Serbia has taken the lead in Europe on technical cooperation with Beijing. The revival of Hesteel steel plant and construction of Zemun-Borca bridge has immensely boosted China's image in Serbia. Eastern European nations will find it hard to resist the temptation of being lured by soft loans offered by Export Import bank of China. China is currently modernizing the Serbian rail network at a cost of \$ 25.6 million. Poland's quality dairy products are highly sought after by Chinese locals.

China has submitted a proposal for constructing a bullet train line between Bangalore to Chennai in India. But the matter has now become sidelined due to the escalating tensions at the border. An approximate figure of $\$ 360$ billion has been invested on high speed rail network in China. A major train accident near the city of Wenzhou in 2011 forced China to cut back on speed. Improving connectivity through rail network will 
complement the steps taken on external connectivity through belt road initiative. Urban rail project in Ethiopia and high speed rail in Laos, high speed line between Istanbul and Ankara are among other rail projects initiated by China.

A part of the spending on infra structure goes towards establishing new ports and developing existing ones. In Africa, China is constructing the Lamu port in Kenya, and funding the Bagamoyo port in Tanzania. Cosco shipping, a merged entity of Cosco and China shipping, owns the majority stake in the Piraeus port authority of Greece. The Chinese exports shipped to the Greek port of Piraeus are then transported by rail to European nations. The Mediterranean country of Egypt has received considerable investment for its banking sector from china. Though it is early to predict the long term effects of China's engagement with it's new allies, a realignment of the global power structure is surely on the cards.

\section{Conclusion}

As part of the ongoing reforms, $\mathrm{Xi}$ Jinping has ordered a crackdown on corruption involving party officials, army generals and is restructuring the army. The anti graft drive has shaken the upper echelons of China's government with party officials like Wang Min, the leader of Liaoning province, former security czar Zhou Yongkang and army officials being convicted of bribery charges. Recent developments indicate that the raids were actually done to arrest those involved in a coup attempt against the government. The recent arrests and the reduction in troop level shows that army would no longer enjoy unparalleled power. ${ }^{10}$ Global integration would prove to be a distant dream for China, unless it provides a free platform for the internet users. Contrary to expectation, it has recently placed more restrictions on Facebook, WhatsApp. It would be in the best interests of Beijing to recognize and affirm universal human rights. ${ }^{11}$

U.S is locked in a trade dispute with china over trade imbalance and intellectual property violations. China has warned that the existing trade agreements with U. S will become void if the latter applies punitive measures. This is a clear signal that it will not hesitate to step up the pressure when deemed necessary. Beijing has agreed to buy $\$ 70$ billion worth of American goods in order to reduce the trade imbalances. America has increased pressure on China over its support to North Korea by threatening to sue over violation of intellectual property rights. Intellectual property violations are used as a tool to gain concessions on other issues like North Korea. The recent rapproachment between North Korea and the U. S wouldn't have been possible without the tacit support of China. Trump has relaxed sanctions on the Chinese firm ZTE in recognition of China's efforts in facilitating the summit held with Kim Jong. There exists a possibility that a reunified, Democratic Korea might move away from China's sphere of influence and become closer to America.

Intense competition exists between India and China over securing the support of third world countries. This is clearly evident in the roles played by regional forums like AAGC, BRICS. BRICS symbolises the potential of Indo - China cooperation and will serve as a model to emulate for developing countries. The $2+1$ dialogue mechanism proposed by China for dealing with south Asian countries, involves India as the other negotiating partner. India has become a priority in Xi Jinping's scheme of things after America entrusted the security of the pacific region to India. Fostering a culture of peace with it's neighbours will free Beijing to work on removing the principle contradictions in the 
Chinese society, and to achieve the centenary goals. The economic benefits haven't trickled down to the poor and this remains as the principle contradiction in the Chinese society. China should understand it's responsibility to maintain global stability and needs to act in a concerted manner with the international community. After all, China is not demanding much in seeking a claim in the global power structure to which they have contributed in no small measure.

\section{Endnotes}

${ }^{1}$ Syrian ambassador to China has quoted about 5000 Uighyurs fighting for the Islamic state in Syria and this is making China to get involved in resolving the Syrian crisis. While this figure might be slightly exaggerated, Chinese estimates are around 200 Uighyurs fighting in Syria. It is evident that China will grab a dominant share of the post war reconstruction projects. Huwaei, the Chinese telecommunication giant is under the scanner from American security agencies for its dealings in Syria. During the meeting with his Syrian counterpart at the sidelines of UN assembly meeting, Chinese Foreign Minister Wang Yi emphasized on the fact that Syria is a important node in the obor project. Syria's role in the obor would be as a connecting point between Iran and Europe. Beijing has indicated that the belt road initiative will be adjusted to accommodate reconstruction work in Syria. The high profile visit of Rear Admiral Guan Youfe to Damascus, who heads the office for international military cooperation prompted India to express solidarity with the Assad regime from which it refrained previously.

${ }^{2}$ Joint collaborations with India will make acceleration on technological innovations easier for China. China's strong manufacturing base in electronics would complement India's expertise in the field of software. Such technical collaboration would help China to reverse its economic slowdown. India and China have also vowed to fight against global protectionism.

${ }^{3}$ China has made its presence felt in every field of Iran's industrial activity starting from the Rudbar Lorestan hydropower dam project undertaken by the Gezhouba group corporation to the Kimaiye Pars methanol plant. India has been expected to develop the Farzad gas field in Iran, but the deal seems to be falling through, because of the shifting of goal posts by Iran. Iran's major trading partner is China and their trade levels stand at $\$ 18$ billion. India being unable to settle the Farzad $-\mathrm{B}$ gas field deal is partly due to Iran's approach to seek wide range of options, and it expects India to avoid heeding America's advice on matters pertaining to it.

${ }^{4}$ The solution for China's environmental problems lies in adopting simple, cost effective methods rather than ones involving huge investment. The Hebei province saw large scale job losses after the closure of polluting industrial units. China has embarked on a massive solar energy programme to replace the coal based power plants.

${ }^{5}$ The raking up the old dispute of Senkaku Island by China has put japan on the backfoot. China tries to influence Japan's foreign policy to be in tune with its interests. Tokyo has adopted a serious approach, not to capitulate to Chinese demands, and to negotiate from a position of strength. India remains the only Asian nation with enough military capability and geographical size to defend against the superior Chinese conventional strength. Japan and India share mutual interests in promoting peace in the Asia pacific region.

${ }^{6}$ South Asian Nations remain worried over the threat looming on unrestricted access to the South China Sea. ASEAN countries are hoping that India's presence in South 
China Sea will deter aggression from China. Indian navy can contribute in a major way in preserving the maritime security. The status of not being a permanent member of ASEAN hinders India from acting with authority. The best way to make China flexible is by convincing it about the merits of cooperation and this was apparent in the case of Scarborough shoal, where china stopped reclamation work in reciprocity for Philippines shelving its enhanced defence cooperation agreement with the U.S.

${ }^{7}$ Washington's hesitancy to act tough on china sends mixed signals to the south Asian countries Trump's recent visit to China was dominated by trade agreements and less attention was paid to south china sea dispute. The trump administration is relying on japan and India to balance China instead of directly confronting it. The new security policy of the U.S has affirmed its support to India's emergence as a global power. The formation of a quadrilateral to counter balance China remains the best option in the current scenario.U.S is moving into a isolationist mode with the officially supported America first doctrine and this might encourage China to assert it's dominance.

${ }^{8}$ China's inability to persuade n. Korea to end missile tests is a matter of serious concern. Carla P. Freeman (2015).North Korea's missiles are pointed at South Korean cities and any major provocation will lead to an all out war. The safety of American troops stationed in South Korea will be put to risk if hostilities break out.

${ }^{9}$ There exists a opinion that border dispute with India isn't a matter of high priority for China, but the memories of 1962 war still continues to haunt India (Saran 2017a, 2017b).Tensions soared along the Indo-China border in August 2017 after troops buildup by both the sides at Dokhlam region. See PTI News 2017. Modi's bilateral meeting with Xi Jinping in Xiamen helped to achieve a standoff truce on Dokhlam dispute, and both leaders agreed on enhancing bilateral dialogue.

${ }^{10}$ The arrest of the higher ranked officials and the subsequent elevation of bureaucrats closer to Xi Jinping has created a situation, wherein the premier's supremacy will remain unchallenged.(Blackwill and Campbell 2016:pp.3-5). This will help the civilian authority to hold its dominance over the military. Time is ticking for xi jinping to deliver on the promises made by the party to its citizens.Jiang Xemin's socio-political theory of Three Represents has now given way to the Four Comprehensives of Xi Jinping (Sun 2014; Cheng Chen, 2016).Xi Jinping has advocated globalisation as a tool for the development of poorer countries. Xi Jinping's approach could be part of plan to align the country's foreign policy with Mao's third world socialism. The practical application of the concept of socialism with Chinese characteristics is evident in the obor program.

${ }^{11}$ See Reuters 2017.

Abbreviations

AAGC: Asia-Africa Economic Corridor; ASEAN: Association of South East Asian Nations; BRICS: Brazil Russia India China Summit; CPEC: China Pakistan Economic Corridor; OBOR: One Belt One Road Initiative; RCEP: Regional Comprehensive Economic Partnership; S-400: Triumph missile system; Su-35: Sukhoi Su-35 air-defence fighter; THAAD: Terminal High Altitude Area Defense; TPP: Trans Pacific Partnership

Acknowledgements

I am deeply indebted to Helga Haftendorn for her support and advice.

Authors' contributions

The author read and approved the final manuscript. 
Competing interests

The author declares that he has no competing interests.

\section{Publisher's Note}

Springer Nature remains neutral with regard to jurisdictional claims in published maps and institutional affiliations.

Received: 7 March 2018 Accepted: 9 August 2018

Published online: 24 September 2018

References

Allison, Graham. 2017. Destined for War: Can American and China escape Thucydides's Trap? Scribe Publications, 2017 Google Scholar.

Blackwill, Robert D., and Kurt M. Campbell. 2016. Chinese Foreign Policy Under a Powerful but Exposed Leader, Council Special Report No. 74, February 2016. The Council on Foreign Relations (CFR).

Brewster, David. 2012. India as an Asia Pacific power. Routledge Press Google Scholar.

Chen, Cheng. 2016. The return of ideology: The search for regime identities in Postcommunist Russia and China. University of Michigan Press Google Scholar.

Freeman, Carla P. 2015. China and North Korea: Strategic and policy perspectives from a changing China. Palgrave Macmillan Google Scholar.

Harold, Scott Warren, and Alireza Nader. 2012. China and Iran: Economic, Political, and Military Relations, pages 14-16. Rand Corporation.

Hong, Zhao. 2015. China and ASEAN: Energy security, cooperation and competition, pages 170-175. ISEAS-Yusof Ishak Institute Google Scholar.

Kissinger, Henry. 2011. On China, Henry Kissinger. Penguin Press Google Scholar.

Li, Mingjiang, and Chong Guan Kwa. 2011. China-ASEAN Sub-regional Cooperation:Progress, Problems and Prospect, pages 105108. World Scientific Publishers.

Liao, Xuanli. 2006. Chinese foreign policy think tanks and China's policy towards Japan. Chinese University Press Google Scholar. Bertil Lintner,(2018), China's India War:Collision Course on the Roof of the World Oxford University Press.

Vince F. Nonato. 2017.http://newsinfo.inquirer.net/939735/leni-robredo-china-debt-trap-rodrigo-duterte\#ixzz4wJCXfXdK

PTI. 2017.http://www.thehindu.com/news/national/doklam-derails-chennai-mysuru-high-speed-train-project/article19866475.ece

PTI. 2018. https://www.financialexpress.com/india-news/xi-jinping-says-china-india- are-backbone-of-worlds-multipolarisationeconomic-globalisation/1148925/.

Ramay, Shakeel Ahmad. 2016. China Pakistan economic corridor a Chinese dream being materialized through Pakistan. Islamabad: Sustainable development policy institute.

Reuters. 2017. https://www.reuters.com/article/us-china-congress-tibet/china-says-no-excuses-for-foreign-officials-meetingdalai-lama-idUSKBN1CQ057.

Ian E. Rinehart (2016) The Chinese Military: Overview and Issues for Congress, Pages 20-21, Congressional Research Service 7-5700 www.crs.gov R44196.

Easwaran Rutnam,2017, http://www.thesundayleader.lk/2017/07/30/beijing-not-fully-satisfied-with-hambantota-port-deal/ Saran, Shyam. 2017a. How India sees the world: Kautilya to the 21st century. Juggernaut publications.

Saran, Shyam. 2017b. How India sees the world: Kautilya to the 21st century. Juggernaut Publishers.

Schott, Jeffrey J., Barbara Kotschwar, and Julia Muir. 2012. Understanding the trans-Pacific partnership. Peterson Institute for international economics.

Shambaugh, David. 2011. China Goes global: The partial power, pages 200-203. Oxford University Press USA Google Scholar. Wanning Sun,(2014) Subaltern China: Rural migrants, media, and Cultural Practices-Rowman \& Littlefield. Google Scholar. Vandewalle, Laurence. 2015. Pakistan and China: Iron brothers' forever?, Policy Department, Directorate -General For External Policies. European parliament.

Xinhuanet. 2018.Full text of Chinese president Xi Jinping's speech at the $18^{\text {th }}$ SCO Qingdao summit. http://www.xinhuanet. com/english/2018-06/10/c_137244587.htm

\section{Submit your manuscript to a SpringerOpen ${ }^{\circ}$ journal and benefit from:}

- Convenient online submission

- Rigorous peer review

- Open access: articles freely available online

- High visibility within the field

- Retaining the copyright to your article

Submit your next manuscript at $\boldsymbol{\nabla}$ springeropen.com 